\title{
KERANGKA DASAR PENYUSUNAN DAN PENYAJIAN \\ LAPORAN KEUANGAN SYARIAH
}

\author{
Oleh: Rahmat Ilyas ${ }^{1}$
}

\begin{abstract}
Islamic transactions based on the basic paradigm that the universe was created by God as amanah (trust Divine) and means the joy of life for all mankind to prosper materially and spiritually intrinsic (Al-falah). The basic paradigm emphasizes every buman activity has accountability and divine values that put the sharia and morals as parameters of good and bad, right and wrong with the business activity. Financial reporting is the structure and process of accounting that describes how the financial information provided and reported to achieve the goal of economic and social state
\end{abstract}

Keywords: Transaction, welfare, financial statements

\section{A. Pendahuluan}

Perbankan syariah merupakan bagian dari entitas syariah yang berfungsi sebagai lembaga intermediary keuangan diharapkan dapat menampilkan dirinya secara baik dibandingkan dengan perbankan dengan sisitem yang lain (perbankan yang berbasis bunga). Gambaran tentang baik buruknya suatu perbankan syariah dapat dikenali melalui kinerjanya yang tergambar dalam laporan keuangan. ${ }^{2}$

Penyajian laporan akuntansi bank syariah telah diatur dengan pedoman standar akuntansi keuangan syariah (PSAK) dan pedoman akuntansi perbankan syariah Indonesia (PAPSI). Oleh karena itu, laporan keuangan harus mampu memfasilitasi semua pihak yang terkait dengan bank syariah. Kekurangan perhatian PSAK dan PAPSI dalam masalah syariah juga terdapat dalam hal fungsi laporan keuangan memfasilitasi DPS untuk memeriksa dana non halal yang diterima oleh bank. Dana non halal berdasarkan PSAK no. 59 dan PAPSI digabung dengan dana

${ }^{1}$ Dosen Jurusan Syariah dan dan Ekonomi Islam STAIN Syaikh Abdurahman Siddik Bangka Belitung email: mtd_82@yahoo.com

2 Dwi Suwikno, Analisis Laporan Kenangan Perbankan Syariah, (Yogyakarta, Pustaka Pelajar, 2010), hlm. 118 
Qardh. Penggabungan dapat menimbulkan persoalan syariah berupa tercampurnya yang hak dan yang bathil. Ketiadaan pemisahan akan menyebabkan kurangnya perhatian untuk mengupayakan pengeliminasian dan non halal dimasa yang akan datang. ${ }^{3}$

Laporan keuangan adalah laporan periodik yang disusun menurut prinsipprinsip akuntansi yang diterima secara umum tentang status keuangan dari individu, asosiasi, atau organisasi bisnis yang terdiri dari neraca, laporan laba rugi, dan laporan perubahan ekuitas pemilik.

Laporan keuangan bank sama saja dengan laporan keuangan perusahaan. Neraca bank memperlihatkan gambaran posisi keuangan suatu bank pada saat tertentu. Laporan laba-rugi memperlihatkan hasil kegiatan atau operasional suatu bank selama satu periode tertentu. Laporan perubahan posisi keuangan memperlihatkan darimana saja sumber dana bank dan kemana saja adana disalurkan. Laporan ini disusun dari neraca pada dua periode dan laporan laba-rugi selama periode yang dilaporkan. Selain dari ketiga komponen utama laporan keuangan diatas, juga harus disertakan catatan dan laporan lain serta materi penjelasan yang merupakan bagian integral dari laporan keuangan. ${ }^{4}$

Berbeda dengan perusahaan lainnya, bank diwajibkan menyertakan laporan komitmen dan kontijensi, yaitu memberikan gambaran, baik yang bersifat tagihan maupun kewajiban pada tanggal laporan.

\section{B. Paradigma Transaksi Syariah}

Transaksi syariah berlandaskan pada paradigma dasar bahwa alam semesta dicipta oleh Tuhan sebagai amanah (kepercayaan Ilahi) dan sarana kebahagiaan hidup bagi seluruh umat manusia untuk mencapai kesejahteraan hakiki secara material dan spiritual (alfalah). Paradigma dasar ini menekankan setiap aktivitas umat manusia memiliki akuntabilitas dan nilai ilabiyah yang menempatkan perangkat syariah dan akhlak sebagai parameter baik dan buruk, benar dan salahnya aktivitas usaha. Paradigma ini akan

${ }^{3}$ Muhammad, Manajemen Keuangan Syariah; analisis Fiqh \& Keuangan, (Yogyakarta:UPP STIM YKPN, 2014), hlm. 83

4 Veithzal Rivai \& Arviyan Arifin, Islamic Banking, (Jakarta: Bumi Aksara, 2010), hlm. 876 
membentuk integritas yang membantu terbentuknya karakter tata kelola yang baik (good governance) dan disiplin pasar (market discipline) yang baik.

Syariah merupakan ketentuan hukum Islam yang mengatur aktivitas umat manusia yang berisi perintah dan larangan, baik yang menyangkut hubungan interaksi vertikal dengan Tuhan maupun interaksi horizontal dengan sesama makhluk. Prinsip syariah yang berlaku umum dalam kegiatan muamalah (transaksi syariah) mengikat secara hukum bagi semua pelaku dan stakeholder perbankan yang melakukan transaksi syariah. Akhlak merupakan norma dan etika yang berisi nilai-nilai moral dalam interaksi sesama makhluk agar hubungan tersebut menjadi saling menguntungkan, sinergis dan harmonis. Transaksi syariah berasaskan pada prinsip :

1. Persaudaraan (ukhuwah);

2. Keadilan ('adalab);

3. Kemaslahatan (maslahah);

4. Keseimbangan (tawazun);

5. Universalisme (syumuliyah). ${ }^{5}$

Prinsip persaudaraan (ukhuwah) esensinya merupakan nilai universal yang menata interaksi sosial dan harmonisasi kepentingan para pihak untuk kemanfaatan secara umum dengan semangat saling menolong, Transaksi syariah menjunjung tinggi nilai kebersamaan dalam memperoleh manfaat (sharing economics) sehingga seseorang tidak boleh mendapat keuntungan di atas kerugian orang lain. Ukhuwah dalam transaksi syari'ah berdasarkan prinsip saling mengenal (ta'aruf), saling memahami (tafahum), saling menolong (ta'awun), saling menjamin (takaful), saling bersinergi dan beraliansi (tabalu.f).:

Prinsip keadilan adalah esensinya menempatkan sesuatu hanya pada tempatnya dan mernberikan sesuatu hanya pada yang berhak serta memperlakukan sesuatu sesuai posisinya. Implementasi keadilan dalam kegiatan usaha berupa a turan prinsip muamalah yang melarang adanya unsur:

5 Ikatan Akuntan Indonesia (IAI), Kerangka Dasar Penyusunan dan Penyajian Laporan Lembaga Keuangan Syariah (KDPPLKS), tahun 2007, Paragraf 15, hlm. 6 
1. Riba (unsur bunga dalam segala bentuk dan jenisnya, baik riba nasiah maupun fadhl):

2. Kezaliman (unsur yang merugikan dirisendiri, orang lain, maupun lingkungan);

3. Maysir (unsur judi dan sikap spekulatif);

4. Gharar (unsur ketidakjelasan):

5. Haram (unsur haram baik dalam barang maupun jasa serta aktivitas operasional yang terkait). ${ }^{6}$

Esensi riba adalah setiap tambahan pada pokok piu tang yang dipersyaratkan dalam transaksi pinjam-meminjam serta derivasinya dan transaksi tidak tunailainnya, dan setiap tambahan yang dipersyaratkan dalam transaksi pertukaran antarbarang-barang ribawi termasuk pertukaran money exchange) yang sejenis secara tunai maupun tangguh dan yang tidak sejenis secara tidak tunai.

Esensi kezaliman (dzulm) adalah menempatkan sesuatu tidak pada tempatnya, mernberikan sesuatu tidak sesuai ukuran, kualitas dan temponya. mengambil sesuatu yang bukan haknya dan memperlakukan sesuatu tidak sesuai posisinya. Kezaliman dapat menimbulkan kemudharatan bagi masyarakat secara keseluruhan, bukan hanya sebagian; atau membawa kemudharatan bagi salah satu pihak atau pihak-pihakyang melakukan transaksi,

Esensi maysir adalah setiap transaksi yang bersifat spekulatif dan tidak berkaitan dengan produktivitas serta bersifat perjudian (gambling). Esensi gharar adalah setiap transaksi yang berpotensi merugikan salah satu pihak karena mengandung unsur ketidakjelasan, manipulasi dan eksploitasi informasi serta tidak adanya kepastian pelaksanaan akad. Bentuk-bentuk gharar antara lain:

1. Tidak adanya kepastian penjual untuk menyerahkan objek akad pada waktu terjadi akad, baik objek akad itu sudah ada maupun belum ada:

6 Ibid, Paragraf 17 hlm. 7 
2. Menjual sesuatu yang belum berada di bawah penguasaan penjual;

3. Tidak adanya kepastian kriteria kualitas dan kuantitas barang/jasa;

4. Tidak adanya kepastian jumlah harga yang harus dibayar dan alat pembayaran;

5. Tidak adanya ketegasan jenis dan objek akad;

6. Kondisi objekakad tidak dapat dijamin kesesuaiannya dengan yang ditentukan dalam transaksi;

7. Adanya unsur eksploitasi salah satu pihak karena informasi yang kurang atau dimanipulasi dan ketidaktahuan atau ketidakpahaman yang ditransaksikan.

Esensi haram adalah segala unsur yang dilarang secara tegas dalam alQuran dan as-Sunah.

Prinsip kemaslahatan (mashlabaii) esensinya merupakan segala bentuk kebaikan dan manfaat yang berdimensi duniawi dan ukhrawi, material dart spiritual, serta indivi• dual dan kolektif. Kemaslahatan yang diakui hams memenuhi dua unsur yakni kepatuhan syari' ah (balal) serta bermanfaat dan membawa kebaikan (thayib) dalam semua aspek secara keseluruhan yang tidak menimbulkan kemudharatan, Transaksi syari'ah yang dianggap bermaslahat harus memenuhi secara keseluruhan unsur-unsur yang menjadi tujuan ketetapan syari'ah (maqashid syari'ab) yaitu berupa pemeliharaan terhadap

1. Akidah, keimanan dan ketakwaan (dien);

2. Intelektual ( aql);

3. Keturunan (nasl):

4. Jiwa 'dan keselamatan (nafs);

5. Harta benda (mal). 
Prinsip keseimbangan (tawazun) esensinya meliputi keseimbangan aspekmaterial dan spiritual, aspek privat dan publik, sektor keuangan dan sektor riil, bisnis dan sosial, dan keseimbangan aspek pemanfaatan dan pelestarian. Transaksi syari' ah tidak hanya menekankan pada maksimalisasi keuntungan perusahaan semata untuk kepentingan pemilik (shareholder). Sehingga manfaat yang didapatkan tidak hanya difokuskan pada pemegang saham, akan tetapi pada semua pihak yang dapat merasakan manfaat adanya suatu kegiatan ekonomi.

Prinsip universalisme (syumuliyah) esensinya dapat dilakukan oleh, dengan, dan untuk semua pihak yang berkepentingan (stakeholder). tanpa membedakan suku, agama, ras dangolongan, sesuai dengan semangat kerahmatan semesta (rabmatan lil alamin). ${ }^{8}$

\section{Karakteristik Transaksi Syari'ah}

Transaksi syariah terikat dengan nilai-nilai etis meliputi aktivitas sektor keuangan dan sektor riil yang dilakukan secara koheren tanpa dikotomi sehingga keberadaan dan nilai uang merupakan cerminan aktivitas investasi dan perdagangan. Implementasi transaksi yang sesuai dengan paradigma dan azas transaksi syari'ah harus memenuhi karakteristik dan persyaratan sebagai berikut:

1. Transaksi hanya dilakukan berdasarkan prinsip saling paham dan saling ridha;

2. Prinsip kebebasan bertransaksi diakui sepanjang objeknya halal dan baik (thayib);

3. Uang hanya berfungsi sebagai alat tukar dan satuan pengukur nilai, bukan sebagai komoditas;

4. Tidak mengandung unsur riba;

5. Tidak mengandung unsur kezaliman;

6. Tidak mengandung unsur maysir;

7. Tidak mengandung unsur gharar;

8. Tidak mengandung unsur haram;

8 Ibid, hlm.9 
9. Tidak menganut prinsip nilai waktu dari uang (time value of money) karena keuntungan yang didapat dalam kegiatan usaha terkait dengan risiko yang melekat pada kegiatan usaha terse but sesuai dengan prinsip alghunmu bil ghurmi (no gain without accompanying risk);

10. Transaksi dilakukan berdasarkan suatu perjanjian yang jelas dan benar serta untuk keuntungan semua pihak tanpa merugikan pihak lain sehingga tidak diperkenankan menggunakan standar ganda harga untuk satu akad serta tidak menggunakan duatransaksi bersamaanyang berkaitan (ta'alluq) dalam satu akad;

11. Tidak ada distorsi harga melalui rekayasa permintaan (najasy), maupun melalui rekayasa penawaran (ibtikar);

12. Tidak mengandung unsur kolusi dengan suap menyuap (risywah).'

\section{Prinsip-prinsip Akuntansi}

Pelaporan keuangan adalah struktur dan proses akuntasi yang menggambarkan bagaimana informasi keuangan disediakan dan dilaporkan untuk mencapai tujuan ekonomik dan sosial negara. Lingkup pelaporan keuangan meliputi struktur dan mekanisme bekerjanya sistem dalam suatu negara. ${ }^{10}$

Struktur akuntansi melukiskan unsur-unsur (pihak-pihak dan sarana-sarana) yang terlibat dalam dan terpengaruh oleh penentuan/penyediaan informasi keuangan dan saling hubungan antara unsur-unsur tersebut. Pihak yang terlibat (berkepentingan) meliputi pelaku dan institusi misalnya penyusun standar, profesi, pemerintah, badan pembina pasar modal, perusahaan sebagai entitas, analis, manajer, akuntan publik, dan pemakai laporan. Sarana-sarana yang membentuk struktur akuntansi meliputi misalnya peraturan pemerintah, standar akuntansi, laporan keuangan, dan konvensi pelaporan. Pengertian proses akuntansi dalam pelaporan keuangan adalah mekanisme tentang bagaimana pihak-pihak dan sarana-sarana pelaporan bekerja dan saling berinteraksi sehingga dihasilkan informasi keuangan

${ }^{9}$ Ikatan Akuntan Indonesia (IAI), Kerangka Dasar Penyusunan dan Penyajian Laporan Lembaga Keuangan Syariah (KDPPLKS), tahun 2007, Paragraf 27 hlm. 10

10 Jefri Heridiansyah dan Sujadi, Fungsi Manajemen Dalam Penyajian Laporan Keuangan, Jurnal STIE Semarang, Vol 3, No 2, Edisi Juni 2011 
yang diwujudkan dalam bentuk laporan/statemen keuangan termasuk mekanisme untuk menentukan kewajaran statemen keuangan.

Standar akuntansi sebagai acuan penyusunan laporan keuangan yang berlaku disuatu negara, akan berbeda dengan standar akuntansi di negara lain. Perbedaan ini dipengaruhi oleh kondisi lingkungan, hukum, sosial, politik dan ekonomi di tiap-tiap negara. Masalah keterbandingan (Comparability) laporan keuangan, tingkat keandalan (reliability) dan peluang ketidakpastian menjadi konsekuensi dari adanya perbedaan standar akuntansi ini. ${ }^{11}$

Akuntansi berfungsi sebagai penyedia data guna penyusunan laporan keuangan dengan syarat data tersebut harus objektif dan informatif bagi kepentingan berbagai pihak yang terkait dengan perusahaan. Agar dapat memenuhi fungsinya diperlukan seperangkat prinsip dan konsep akuntansi dalam pencatatan data dan penyusunan laporan keuangan perusahaan. Prinsip dan konsep akuntansi diantaranya:

1. Konsep kesatuan usaha

Konep ini menyatakan bahwa pencatatan kegiatan perusahaan itu harus dipisahkan dari kegiatan pemiliknya atau rumah tangga pemiliknya.

2. Konsep kelangsungan hidup

Perusahaan didirikan tidak untuk sementara waktu, tetapi diharapkan berjalan terus sepanjang waktu. Azas bahwa hidup sepanjang waktu akan mempengaruhi metode penilaian.

3. Konsep harga pokok

Sehubungan dengan konsep kedua tersebut diatas, data akuntansi akan dicatat menurut harga perolehannya (at cash) pada waktu pristiwa itu terjadi dan tinggal tetap demikian dalam catatan atau laporan akuntansi karena ini merupakan pendekatan yang paling objektif.

4. Konsep kesatuan pengukuran

Pencatatan data akuntansi digunakan satuan ukuran uang (rupiah). Fluktuasi nilai uang dianggap tidak ada pengaruhnya terhadap jumlahjumlah yang ditunjukkan dalam laporan keuangan perusahaan.

11 Aris Tri Cahyono, Meta Teori Standar Akuntansi Keuangan Di Indonesia - Menuju Konvergensi SAK di Masa Globalisasi, Jurnal Eksis Vol.7 No.2, Agustus 2011: 1816 - 2000 
5. Konsep periode waktu

Oleh karena aktivitas perusahaan berjalan sepanjang waktu, proses penyajian kondisi keuangan dan hasil operasi perusahaan perlu dipecah dalam periode-periode tertentu.

6. Konsep objektivitas

Untuk keperluan pencatatan akuntansi dibutuhkan dukungan bukti-bukti transaksi yang bersifat objektif dan dapat diuji kebenarannya.

7. Konsep keterbukaan

Semua fakta-fakta perlu diungkapkan secara terbuka supaya laporan kondisi keuangan dan hasil usaha persahaan sedapat mungkin bersifat informatif dan memberi arti (tidak menyesatkan) bagi pihak-pihak yang berkepentingan.

8. Konsep konsistensi

Didalam akuntansi terdapat beberapa metode yang dapat dipergunakan, misalnya dalam hal penilaian persedian, menentukan besarnya penyusutan, menaksir kerugian piutang yang tidak dapat ditagih. Akuntansi harus memilih salah satu metode yang paling sesuai dengan kebutuhan. Sekali satu metode telah dipilih, maka secara konsisten harus dipertahankan terus dari perode ke periode.

9. Konsep konservatisme

Umumnya konservatisme diartikan sebagai mencatat aset dengan harga yang lebih rendah dari harga perolehannya atau mencatat hutang dengan nilai yang lebih tinggi. Selain itu juga konservatisme juga diberi makna bahwa akuntan mengikuti prinsip mengakui kemungkinan rugi yang akan terjadi, tetapi tidak mengantisipasikan laba yang belum direalisir. ${ }^{12}$

Konservatisme akuntan menyatakan bahwa apabila ada beberapa alternatif akuntansi maka alternatif yang seharusnya dipilih adalah alternatif yang paling kecil kemungkinannya untuk melaporkan aset atau pendapatan lebih besar dari yang seharusnya. Konservatisme timbul

${ }^{12}$ Dwi Suwikno, Pengantar akuntansi Syariah, (Yogyakarta, Pustaka Pelajar, 2010), hlm. 6 
karena ada kecendrungan dari pihak manajemen untuk menaikkan nilai aset dan pendapatan suatu perusahaan. ${ }^{13}$

\section{E. Tujuan Laporan Keuangan dalam Akuntansi Syariah}

Tujuan laporan keuangan adalah menyediakan informasi yang menyangkut posisi keuangan, kinerja serta perubahan posisi keuangan suatu perbankan syari'ah yang bermanfaat bagi sejumlah besar pemakai dalam pengambilan keputusan ekonomi. Di samping itu, tujuan lainnya adalah:

1. Meningkatkan kepatuhan terhadap prinsip syari'ah dalam semua transaksi dan kegiatan usaha;

2. Informasi kepatuhan perbankan syari' ah terhadap prinsip syari' ah, serta informasi aset, kewajiban, pendapatan dan beban yang tidak sesuai dengan prinsip syari'ah bila ada dan bagaimana perolehan: dan peng gunaannya;

3. Informasi untuk membantu mengevaluasi pemenuhan tanggungjawab perbankan syari'ah terhadap amanah dalam mengamankan dana, menginvestasikannya pada tingkat keuntungan yang layak; dan

4. Informasi mengenai tingkat keuntungan investasi yang diperoleh penanam modal dan pemilik dana syirkah temperer: dan informasi mengenai pemenuhan kewajiban (obligation) fungsi sosial perbankan syari'ah, termasuk pengelolaan dan penyaluran zakat, infak, sedekah, dan wakaf.

Laporan keuangan yang disusun untuk tujuan ini memenuhi kebutuhan bersama sebagian besar pernakai. Namun demikian, laporan keuangan tidak menyediakan semua inforrnasi yang mungkin dibutuhkan pemakai dalam pengambilan keputusan ekonomi karena secara umum menggambarkan pengaruh keuangan dari kejadian di masa lalu, dan tidak diwajibkan untuk menyediakan informasi nonkeuangan. Laporan keuangan juga

${ }^{13}$ Mamduh M Hanafi \& Abdul Halim, Analisis Laporan Kenangan, (Yogyakarta, UPP STIM YKPN, 2007), hlm. 41 
menunjukan apa yang telah dilakukan manajemen (stewardship), atau pertanggungjawaban manajemen atas sumber daya yang dipercayakan kepadanya. Pemakai yang ingin menilai apa yang telah dilakukan atau pertanggungjawaban manajemen berbuat demikian agar mereka dapat membuat ke putusan ekonomi: keputusan ini mungkin mencakup, misalnya, keputusan untuk menahan atau menjual investasi mereka dalam perbankan syari'ah atau keputusan untuk rnengangkat kembali atau mengganti manajemen.

Sedangkan dalam PSAK 101 disebutkan bahwa Laporan keuangan adalah suatu penyajian terstruktur dari posisi keuangan dan kinerja keuangan suatu entitas syariah. Tujuan laporan keuangan adalah untuk memberikan informasi mengenai posisi keuangan, kinerja keuangan dan arus kas entitas syariah yang bermanfaat bagi sebagian besar pengguna laporan keuangan dalam membuat keputusan ekonomik. Laporan keuangan juga menunjukkan hasil pertanggungjawaban manajemen atas penggunaan sumber daya yang dipercayakan kepada mereka. Dalam rangka mencapai tujuan tersebut, suatu laporan keuangan menyajikan informasi mengenai entitas syariah yang meliputi:

1. aset;

2. kewajiban;

3. dana syirkah temporer;

4. ekuitas;

5. pendapatan dan beban termasuk keuntungan dan kerugian;

6. arus kas;

7. dana zakat; dan

8. dana kebajikan. ${ }^{14}$

\section{F. Tujuan Laporan Keuangan dalam Akuntansi Konvensional}

Tujuan laporan keuangan adalah menyediakan informasi yang menyangkut posisi keuangan, kinerja serta perubahan posisi keuangan suatu perusahaan yang bermanfaat bagi sejumlah besar pemakai dalam pengambilan keputusan ekonomi.

${ }^{14}$ Ikatan Akuntan Indonesia, PS AK 101 Penyajian Laporan Keuangan Syariah, 2014, Paragraf 9 
Laporan keuangan yang disusun untuk tujuan ini memenuhi kebutuhan bersama sebagian besar pemakai. Namun demikian, laporan keuangan tidak menyediakan semua informasi yang mungkin dibutuhkan pemakai dalam pengambilan keputusan ekonomi karena secara umum menggambarkan pengaruh keuangan dari kejadian di masa lalu, dan tidak diwajibkan untuk menyediakan informasi nonkeuangan.

Laporan keuangan juga menunjukkan apa yang telah dilakukan manajemen (stewardship), atau pertanggungjawaban manajemen atas sumber daya yang dipercayakan kepadanya. Pemakai yang ingin menilai apa yang telah dilakukan atau pertanggungjawaban manajemen berbuat demikian agar mereka dapat membuat keputusan ekonomi; keputusan ini mungkin mencakup, misalnya, keputusan untuk menahan atau menjual investasi mereka dalam perusahaan atau keputusan untuk mengangkat kembali atau mengganti manajemen. ${ }^{15}$

\section{G. Keterbatasan Laporan Keuangan}

Laporan keuangan yang dibuat oleh manajemen mempunyai tujuan untuk memberikan informasi dari posisi keuangan dan perubahan posisi keuangan secara periodik yang dilakukan oleh pihak manajemen perusahaan. Laporan keuangan bersifat histroris karena laporan keuangan merupakan akumulasi dari transaksi yang telah terjadi dalam suatu perusahaan dalam masa yang bersangkutan, dan bersifat menyeluruh karena merupakan akumulasi dari seluruh kegiatan usaha yang dapat diukur atau dinyatakan dengan uang.

Dengan karakteristik yang melekat, dapat diidentifikasikan beberapa keterbatasan laporan keuangan yaitu:

1. Laporan keuangan yang dibuat secara periodek pada dasarnya merupakan interim report (laporan yang dibuat antara waktu tertentu yang sifatnya sementara dan bukan merupakan laporan yang final).

2. Laporan keuangan menunjukkan angka dalam rupiah yang kelihatannya bersifat pasti dan tepat, tetapi sebenarnya dasar penyusunannya dengan standar nilai yang mungkin berbeda atau berubah-ubah.

15 Ikatan Akuntan Indonesia, KDPPLK, Paragraf 12-14 
3. Laporan keuangan disusun berdasarkan hasil pencatatan transaksi keuangan atau nilai rupiah dari berbagai waktu atau tanggal yang lalu, dimana daya beli uang tersebut semakin menurun, dibandingkan dengan tahun-tahun sebelumnya, sehingga kenaikan volume penjualan yang dinyatakatkan dalam rupiah belum tentu menunjukkan atau mencerminkan unit yang dijual semakin besar, mungkin kenaikan itu disebabkan naiknya harrga jual barang tersebut yang mungkin juga diikuti tingkat kenaikan harga.

4. Laporan keuangan tidak dapat mencerminkan berbagai faktor yang dapat mempengaruhi posisi atau keadaan keuangan perusahaan karena faktorfaktor tersebut tidak dapat dinyatakan dengan satuan uang. ${ }^{16}$

\section{H. Asumsi Dasar}

Untuk mencapai tujuannya, laporan keuangan disusun atas dasar akrual. Dengan dasar ini, pengaruh transaksi dan peristiwa lain diakui pada saat kejadian (dan bukan pada saat kas atau setara kas diterima atau dibayar) dan diungkapkan dalam catatan akuntansi serta dilaporkan dalam laporan keuangan pada periode yang bersangkutan. Laporan keuangan yang disusun atas dasar akrual memberikan informasi kepada pemakai tidak hanya transaksi masa lalu yang melibatkan penerimaan dan pembayaran kas tetapi juga kewajiban pembayaran kas di masa depan serta sumber daya yang merepresentasikan kas yang akan diterima di masa depan. Oleh karena itu, laporan keuangan menyediakan jenis informasi transaksi masa lalu dan peristiwa lainnya yang paling berguna bagi pemakai dalam pengambilan keputusan ekonomi.

Penghitungan pendapatan untuk tujuan pembagian hasil usaha menggunakan dasar kas. Dalam hal prinsip pembagian hasil usaha berdasarkan bagi hasil, pendapatan atau hasil yang dimaksud adalah keuntungan bruto (gross profit). ${ }^{17}$

Penentuan pendapatan dan biaya dari posisi harta dan kewajiban ditetapkan tanpa melihat transaksi kas telah dilakukan atau tidak. Penentuannya bukan

${ }^{16}$ Suhardi dkk, Akuntansi Pengantar, (Bangka Belitung, UBB Press Pangkalpinang, 2009), hlm.

17 IAI, KDPPLKS...... Pragraf 41-42 
keterlibatan kas, tetapi didasarkan pada faktor legalnya apakah memang sudah merupakan hak (pendapatan) atau kewajiban (biaya) perusahaan atau belum. Kalau sudah, harus dicatat tanpa menunggu pembayaran atay peneriman kas. ${ }^{18}$

Penyusunan atau pencatatan laporan keuangan yang disusun berdasarkan accrual basis dinyatakan juga dalam Fatwa DSN No.14 tahun 2000 yang menyatakan bahwa:

1. Pada prinsipnya, LKS boleh menggunakan sistem Accrual Basis maupun Cash Basis dalam pencatatan administrasi keuangan.

2. Dilihat dari segi kemaslahatan (al-ashlab), dalam pencatatan sebaiknya digunakan sistem acrual basis, akan tetapi dalam distribusi hasil usaha hendaknya ditentukan atas dasar penerimaan yang benar-benar terjadi (cash basis).

3. Penetapan sistem yang harus dipilih harus disepakati dalam akad. ${ }^{19}$

\section{Karakteristik Kualitatif Laporan Keuangan}

Karakteristik kualitatif merupakan ciri khas yang membuat informasi dalam laporan keuangan berguna bagi pemakai. Terdapat empat karakteristik kualitatif pokok yaitu, dapat dipahami, relevan, keandalan, dan dapat diperbandingkan.

1. Laporan Dapat dipahami

Pertama, Kualitas penting informasi yang ditampung dalam laporan keuangan adalah kemudahannya untuk segera dapat dipahami oleh pemakai. Untuk maksud ini, pemakai diasumsikan memiliki pengetahuan yang memadai tentang aktivitas ekonomi dan bisnis, akuntansi, serta kemauan untuk mempelajari informasi dengan ketekunan yang wajar. Namun demikian, informasi kompleks yang seharusnya dimasukkan dalam laporan keuangan tidak dapat dikeluarkan hanya atas dasar pertimbangan bahwa nformasi tersebut terlalu sulit untuk dapat dipahami oleh pemakai tertentu.

2. Laporan Relevan,

18 Arfan Ikhsan dkk, Teori Akuntansi, (Bandung, Citapustaka Media, 2015), hlm. 58

19 Dewan Syariah Nasional MUI, Himpunan Fatwa Keuangan Syariah, (Jakarta, Erlangga, 2014), hlm. 782 
agar bermanfaat informasi harus relevan untuk memenuhu kebutuhan pemakai dalam proses pengambilan keputusan. Informasi memiliki kualitas relevan kalau dapat mempengaruhi keputusan ekonomi pemakai dengan membantu mereka mengevaluasi peristiwa masa lalu, masa kini atau masa depan, menegaskan, atau mengoreksi, hasil evaluasi mereka dimasa lalu.

Relevansi informasi dipengaruhi oleh hakikat dan materialitasnya. Dalam beberapa kasus hakikat informasi saja sudah cukup untuk menentukan relevansi. Misalnya pelaporan suatu segmen baru dapat mempengaruhi penilaian risiko dan peluang yang dihadapi perbankan syariah tanpa mempertimbangkan materialitas dari hasil yang dicapai segmen baru tersebut dalam periode pelaporan.

3. Laporan harus andal

Agar bermanfaat, informasi juga harus andal (reliable). Informasi memiliki kualitas andal jika bebas dari pengertian yang menyesatkan, kesalahan material, dan dapat diandalkan pemakainya sebagai penyajian yang tulus atau jujur (faithful representation) dari yang seharusnya disajikan atau yang secara wajar diharapkan dapat disajikan.

Informasi mungkin relevan tetapi jika hakekat atau penyajiannya tidak dapat diandalkan maka penggunaan informasi tersebut secara potensial dapat menyesatkan. Misalnya, jika keabsahan dan jumlah tuntutan atas kerugian dalam suatu tindakan hukum masih dipersengketakan, mungkin tidak tepat bagi entitas syariah untuk mengakui jumlah seluruh tuntutan tersebut dalam neraca, meskipun mungkin tepat untuk mengungkapkan jumlah serta keadaan dari tuntutan tersebut.

4. Laporan dapat dibandingkan.

Pemakai harus dapat memperbandingkan laporan keuangan entitas syariah antar periode untuk mengidentifikasi kecenderungan (trend) posisi dan kinerja keuangan. Pemakai juga harus dapat memperbandingkan laporan keuangan antar entitas syariah untuk mengevaluasi posisi keuangan, kinerja serta perubahan posisi keuangan secara relatif. Oleh karena itu, pengukuran dan penyajian dampak keuangan dari transaksi dan 
peristiwa lain yang serupa harus dilakukan secara konsisten untuk entitas syariah tersebut, antar periode entitas syariah yang sama, untuk entitas syariah yang berbeda, maupun dengan entitas lain.

Implikasi penting dari karakteristik kualitatif dapat diperbandingkan adalah bahwa pemakai harus mendapat informasi tentang kebijakan akuntansi yang digunakan dalam penyusunan laporan keuangan dan perubahan kebijakan serta pengaruh perubahan tersebut. Para pemakai harus dimungkinkan untuk dapat mengidentifikasi perbedaan kebijakan akuntansi yang diberlakukan untuk transaksi serta peristiwa lain yang sama dalam sebuah entitas syariah dari satu periode ke periode dan dalam entitas syariah yang berbeda. Ketaatan pada standar akuntansi keuangan syariah, termasuk pengungkapan kebijakan akuntansi yang digunakan oleh entitas syariah, membantu pencapaian daya banding.

Kebutuhan terhadap daya banding jangan dikacaukan dengan keseragaman semata-mata dan tidak seharusnya menjadi hambatan dalam memperkenalkan standar akuntansi keuangan syariah yang lebih baik. Entitas syariah tidak perlu meneruskan kebijakan akuntansi yang tidak lagi selaras dengan karakteristik kualitatif relevansi dan keandalan. Entitas syariah juga tidak perlu mempertahankan suatu kebijakan akuntansi kalau ada alternatif lain yang lebih relevan dan lebih andal.

Berhubung pemakai ingin membandingkan posisi keuangan, kinerja serta perubahan posisi keuangan antar periode, maka entitas syariah perlu menyajikan informasi periode sebelumnya dalam laporan keuangan. ${ }^{20}$

\section{J. Unsur-unsur Laporan Keuangan dalam Akuntansi Syariah}

Sesuai karakteristik maka laporan keuangan entitas syariah antara lain meliputi:

1. komponen laporan keuangan yang mencerminkan kegiatan komersial:

a. laporan posisi keuangan;

${ }^{20}$ IAI, KDPPLKS, Paragraf 45-48 dan 52-53, 60-63 
b. laporan laba rugi;

c. laporan arus kas; dan

d. laporan perubahan ekuitas.

2. komponen laporan keuangan yang mencerminkan kegiatan sosial:

a. laporan sumber dan penggunaan dana zakat; dan

b. laporan sumber dan penggunaan dana kebajikan.

3. komponen laporan keuangan lainnya yang mencerminkan kegiatan dan tanggung jawab khusus entitas syariah tersebut.

Unsur yang berkaitan secara langsung dengan pengukuran posisi keuangan adalah aset, kewajiban, dana syirkah temporer dan ekuitas. Pos-pos ini didefinisikan sebagai berikut:

1. Aset adalah sumber daya yang dikuasai oleh entitas syariah sebagai akibat dari peristiwa masa lalu dan dari mana manfaat ekonomi di masa depan diharapkan akan diperoleh entitas syariah.

2. Kewajiban merupakan hutang entitas syariah masa kini yang timbul dari peristiwa masa lalu, penyelesaiannya diharapkan mengakibatkan arus keluar dari sumber daya entitas syariah yang mengandung manfaat ekonomi.

3. Dana syirkah temporer adalah dana yang diterima sebagai investasi dengan jangka waktu tertentu dari individu dan pihak lainnya dimana entitas syariah mempunyai hak untuk mengelola dan menginvestasikan dana tersebut dengan pembagian hasil investasi berdasarkan kesepakatan.

4. Ekuitas adalah hak residual atas aset entitas syariah setelah dikurangi semua kewajiban dan dana syirkah temporer. ${ }^{21}$

\section{K. Unsur-unsur Laporan Keuangan dalam Akuntansi Konvensional}

Laporan Keuangan menggambarkan dampak keuangan dari transaksi dan peristiwa lain yang diklasifikasikan dalam beberapa kelompok besar menurut

${ }^{21}$ IAI, KDPPLKS, Paragraf 71 
karakteristik ekonominya. Kelompok besar ini merupakan unsur laporan keuangan. Unsur yang berkaitan secara langsung dengan pengukuran posisi keuangan adalah aktiva, kewajiban dan ekuitas. Sedang unsur yang berkaitan dengan pengukuran kinerja dalam laporan laba rugi adalah penghasilan dan beban. Laporan perubahan posisi keuangan biasanya mencerminkan berbagai unsur laporan laba rugi dan perubahan dalam berbagai unsur neraca; dengan demikian, kerangka dasar ini tidak mengidentifikasikan unsur laporan perubahan posisi keuangan secara khusus.

Penyajian berbagai unsur ini dalam neraca dan laporan laba rugi memerlukan proses sub-klasifikasi. Misalnya, aktiva dan kewajiban dapat diklasifikasikan menurut hakekat atau fungsinya dalam bisnis perusahaan dengan maksud untuk menyajikan informasi dengan cara yang paling berguna bagi pemakai untuk tujuan pengambilan keputusan ekonomi. ${ }^{22}$

\section{Pengakuan Unsur Laporan Keuangan dalam Akumtansi Syariah}

Pengakuan (recognition) merupakan prosespembentukan suatu pos yang memenuhi definisi unsur serta kriteria pengakuan yang dikemukakan dalam paragraf 110 dalam neraca atau laporan laba rugi. Pengakuan dilakukan dengan menyatakan pos tersebut baik dalam kata-kata maupun dalam jumlah uang dan mencantumkannya ke dalam neraca atau laporan laba rugi. Pos yang memenuhi kriteria tersebut harus diakui dalam neraca atau laporan laba rugi. Kelalaian untuk mengakui pos semacam itu tidak dapat diralat melalui pengungkapan kebijakan akuntansi yang digunakan maupun melalui catatan atau materi penjelasan.

Dalam pragraf 110. Pos yang memenuhi definisi suatu unsur harus diakui kalau:

1. Ada kemungkinan bahwa manfaat ekonomi yang berkaitan dengan pos tersebut akan mengalir dari atau ke dalam entitas syariah; dan

2. Pos tersebut mempunyai nilai atau biaya yang dapat diukur dengan andal.

${ }^{22}$ IAI, KDPPLK, Paragraf 47-48 
Dalam mengkaji apakah suatu pos memenuhi kriteria ini dan karenanya memenuhi syarat untuk diakui dalam laporan laba rugi, perhatian perlu ditujukan pada pertimbangan materialitas yang dibahas dalam paragraf 49 sampai dengan 51. Hubungan antara unsur berarti bahwa suatu pos yang memenuhi definisi dan kriteria pengakuan untuk unsur tertentu, misalnya, suatu aset, secara otomatis memerlukan pengakuan unsur lain, misalnya, penghasilan atau kewajiban. ${ }^{23}$

Dalam kriteria pengakuan penghasilan, konsep probabilitas digunakan dalam pengertian derajat ketidakpastian bahwa manfaat ekonomi masa depan yang berkaitan dengan pos tersebut akan mengalir dari atau ke dalam entitas syariah. Konsep tersebut dimaksudkan untuk menghadapi ketidakpastian lingkungan operasi entitas syariah. Pengkajian derajat ketidakpastian yang melekat dalam arus manfaat ekonomi masa depan dilakukan atas dasar bukti yang tersedia pada saat penyusunan laporan keuangan. Misalnya, kalau pembayaran suatu piutang besar kemungkinan terjadi (probable) dan tidak ada bukti lain yang bertentangan, maka dapat dibenarkan untuk mengakui piutang tersebut sebagai aset. Namun demikian, jika populasi piutang banyak jumlahnya, maka besar kemungkinan ada yang tidak tertagih; karena itu suatu beban yang merepresentasikan pengurangan manfaat ekonomi yang diharapkan harus diakui.

Kriteria pengakuan suatu pos yang kedua adalah ada tidaknya biaya atau nilai yang dapat diukur dengan tingkat keandalan tertentu (reliable) seperti yang dibahas pada paragraf 52 sampai dengan paragraf 59 kerangka dasar ini. Pada banyak

23 Pragram 49. Relevansi informasi dipengaruhi oleh hakekat dan materialitasnya. Dalam beberapa kasus, hakekat informasi saja sudah cukup untuk menentukan relevansinya. Misalnya, pelaporan suatu segmen baru dapat mempengaruhi penilaian risiko dan peluang yang dihadapi entitas syariah tanpa mempertimbangkan materialitas dari hasil yang dicapai segmen baru tersebut dalam periode pelaporan. Dalam kasus lain, baik hakekat maupun materialitas dipandang penting, misalnya jumlah serta kategori persediaan yang sesuai dengan kebutuhan entitas syariah.

Pragraf 50. Informasi dipandang material kalau kelalaian untuk mencantumkan atau kesalahan dalam mencatat informasi tersebut dapat mempengaruhi keputusan ekonomi pemakai yang diambil atas dasar laporan keuangan. Materialitas tergantung pada besarnya pos atau kesalahan yang dinilai sesuai dengan situasi khusus dari kelalaian dalam mencantumkan (omission) atau kesalahan dalam mencatat (misstatement). Karenanya materialitas lebih merupakan suatu ambang batas atau titik pemisah dari pada suatu karakteristik kualitatif pokok yang harus dimiliki agar informasi dipandang berguna.

Pragraf 51. Dalam hal bagi hasil, dasar yang dibagihasilkan harus mencerminkan jumlah yang sebenarnya tanpa mempertimbangkan pelaksanaan konsep materialitas. (lihat KDPPLKS, tahun 2007 hlm 17-18) 
kasus, biaya atau nilai harus diestimasi;penggunaan estimasi yang layak merupakan bagian esensial dalam penyusunan laporan keuangan tanpa mengurangi tingkat keandalan. Namun demikian, kalau estimasi yang layak tak mungkin dilakukan, pos tersebut tidak diakui dalam neraca atau laporan laba rugi. Misalnya, hasil yang diharapkan dari suatu tuntutan hukum dapat memenuhi definisi baik aset dan penghasilan maupun kriteria probabilitas untuk dapat diakui; namun demikian, kalau tidak mungkin diukur dengan tingkat keandalan tertentu, tuntutan tersebut tidak dapat diakui sebagai aset atau sebagai penghasilan; namun demikian, eksistensi tuntutan harus diungkapkan dalam catatan, materi penjelasan atau schedul tambahan. ${ }^{24}$

\section{Pengakuan Unsur Laporan Keuangan dalam Akuntansi Konvensional}

Pengakuan (recognition) merupakan proses pembentukan suatu pos yang memenuhi definisi unsur serta kriteria pengakuan yang dikemukakan dalam paragraf 83 dalam neraca atau laporan laba rugi. Pengakuan dilakukan dengan menyatakan pos tersebut baik dalam kata-kata maupun dalam jumlah uang dan mencantumkannya ke dalam neraca atau laporan laba rugi. Pos yang memenuhi kriteria tersebut harus diakui dalam neraca atau laporan laba rugi. Kelalaian untuk mengakui pos semacam itu tidak dapat diralat melalui pengungkapan kebijakan akuntansi yang digunakan maupun melalui catatan atau materi penjelasan.

Pos yang memenuhi definisi suatu unsur harus diakui kalau:

1. ada kemungkinan bahwa manfaat ekonomi yang berkaitan dengan pos tersebut akan mengalir dari atau ke dalam perusahaan; dan

2. pos tersebut mempunyai nilai atau biaya yang dapat diukur dengan andal.

Dalam mengkaji apakah suatu pos memenuhi kriteria ini dan karenanya memenuhi syarat untuk diakui dalam laporan laba rugi, perhatian perlu ditujukan pada pertimbangan materialitas yang dibahas dalam paragraf 29 dan 30 . Hubungan antara unsur berarti bahwa suatu pos yang memenuhi definisi dan kriteria pengakuan

${ }^{24}$ IAI, KDPPLKS, Paragraf, 112-113 
untuk unsur tertentu, misalnya, suatu aktiva, secara otomatis memerlukan pengakuan unsur lain, misalnya, penghasilan atau kewajiban. ${ }^{25}$

\section{N. Kesimpulan}

Secara garis besar Kerangka Dasar Penyusunan dan Penyajian Laporan Keuangan Syariah memiliki ruang lingkup yang membahas tentang tujuan laporan keuangan, karakteristik yang menentukan manfaat informasi dalam laporan keuangan dan yang ketiga pengakuan serta unsur-unsur yang membentuk laporan keuangan. Sehingga dengan adanya kerangka ini diharapkan dapat menjadi acuan dalam penyajian laporan keuangan perbankan syariah.

Transaksi syariah berlandaskan pada paradigma dasar bahwa alam semesta dicipta oleh Tuhan sebagai amanah (kepercayaan Ilahi) dan sarana kebahagiaan hidup bagi seluruh umat manusia untuk mencapai kesejahteraan hakiki secara material dan spiritual (alfalah). Paradigma dasar ini menekankan setiap aktivitas umat manusia memiliki akuntabilitas dan nilai ilabiyah yang menempatkan perangkat syariah dan akhlak sebagai parameter baik dan buruk, benar dan salahnya aktivitas usaha. Paradigma ini akan membentuk integritas yang membantu terbentuknya karakter tata kelola yang baik (goodgovernance) dan disiplin pasar (market discipline) yang baik

Transaksi syariah berasaskan pada prinsip :

1. Persaudaraan (ukhuwab);

2. Keadilan ('adalab);

3. Kemaslahatan (maslahab);

4. Keseimbangan (tawazun);

5. Universalisme (syumuliyah)

Laporan keuangan disusun atas dasar akrual. Dengan dasar ini, pengaruh transaksi dan peristiwa lain diakui pada saat kejadian (dan bukan pada saat kas atau setara kas diterima atau dibayar) dan diungkapkan dalam catatan akuntansi serta dilaporkan dalam laporan keuangan pada periode yang bersangkutan. Penyusunan

25 IAI, KDPPLK, Paragraf 82-84 
atau pencatatan laporan keuangan yang disusun berdasarkan accrual basis dinyatakan juga dalam Fatwa DSN No.14 tahun 2000

Penyusunan makalah ini lebih didasari pada sumber utama yang telah ada yaitu Kerangka Dasar Penyusunan dan Penyajian Laporan Keuangan Syariah yang dikeluarkan oeh lembaga Ikatan Akuntan Indonesia yang merupakan lembaga yang bergerak dibidang Akuntan. Sehingga penyusunan makalah ini tidak lepas dari aturan yang telah dibuat dan diharapkan sesuai dengan apa yang seharusnya.

Secara umum Kerangka Dasar Penyusunan dan Penyajian Laporan Keuangan Syariah dengan konvensional tidaklah memiliki perbedaan yang signifikan. Kerangka Dasar Penyusunan dan Penyajian Laporan Keuangan Syariah merupakan penyempurnaan dari Kerangka Dasar Penyusunan dan Penyajian Laporan Keuangan konvensional, dimana pada KDPPLKS memperhatikan aspek-aspek syariah sebagai salah satu landasan atau dasar dalam penyusunan laporan keuangan.

Dengan segala keterbatasan penulis dan referensi yang tersedia, diharapkan tulisan sederhana ini dapat memberi informasi buat kita semua. Amin...

\section{DAFTAR PUSTAKA}

Cahyono, Aris Tri, Meta Teori Standar Akuntansi Kenangan Di Indonesia - Menuju Konvergensi SAK di Masa Globalisasi, Jurnal Eksis Vol.7 No.2, Agustus 2011.

Dewan Syariah Nasional MUI, Himpunan Fatwa Keuangan Syariah, Jakarta, Erlangga, 2014.

Hanafi, Mamduh M \& Abdul Halim, Analisis Laporan Kenangan, Yogyakarta, UPP STIM YKPN, 2007.

Heridiansyah, Jefri dan Sujadi, Fungsi Manajemen Dalam Penyajian Laporan Keuangan, Jurnal STIE Semarang, Vol 3, No 2, Edisi Juni 2011.

Ikatan Akuntan Indonesia (IAI), Kerangka Dasar Penyusunan dan Penyajian Laporan Keuangan Syariah (KDPPLKS), Tahun 2007. , PS AK 101 Penyajian Laporan Kenangan Syariah, 2014.

Ikhsan, Arfan dkk, Teori akuntansi, Bandung, Citapustaka Media, 2015. 
Muhammad, Manajemen Kenangan Syariah; Analisis Fiqh \& Keuangan, Yogyakarta,UPP STIM YKPN, 2014.

Rivai, Veithzal \& Arviyan Arifin, Islamic Banking, Jakarta, Bumi Aksara, 2010.

Suhardi dkk, Akuntansi Pengantar, Bangka Belitung, UBB Press Pangkalpinang, 2009.

Suwikno, Dwi, Pengantar akuntansi Syariah, Yogyakarta, Pustaka Pelajar, 2010.

Analisis Laporan Kenangan Perbankan Syariah, Yogyakarta, Pustaka Pelajar, 2010 